\title{
The Impact of Finance Development on the Income Inequality Between the Urban and the Rural: Evidence From Henan Province in China
}

\author{
ZHENG Quanyuan, LIU Zhilin \\ Henan University, Kaifeng, China
}

\begin{abstract}
Finance is one important factor to promote economic development. Meanwhile, it also has a dubious effect on income inequality in accordance with the prior literatures. In order to promote economic development, most of China's governments provide many policies to boost financial development. However, these policies should also be evaluated with its impact on the income inequality. As one important province in China, Henan also wants to have a rapid economic development with policies on financial development. Therefore, this paper uses the vector autoregressive model to detect the impact of financial development on income inequality between the urban and the rural, and the results suggest one positive impulse on financial development would cause income inequality to be increased immediately, but to be decreased after the fourth period. Thus, Henan's policies on financial development would achieve the goal to promote economic development without the detrimental effect on income inequality.
\end{abstract}

Keywords: financial development, income inequality, economic development, vector autoregressive

\section{Introduction}

As one of the main provinces in China, Henan has the most population, but a less developed economy. However, Henan has experienced a rapid economic growth in recent years with a serious income inequality, especially for the income inequality between the urban and the rural. In order to stimulate economic growth, Henan promotes the development of financial sectors. However, the current studies argue that financial development would put an impact on income inequality. Thus, this paper tries to test how the financial development can affect income inequality, and whether the policies of promoting financial sectors would reach the dual goals of stimulating economic growth and alleviating income inequality between the urban and the rural.

A number of literatures argue that financial development plays an important role in economic development (Mckinnon, 1973; Levine \& Zervos, 1998). Meanwhile, the relationship between economic development and income inequality can be described as the Kuznets Curve, which suggests that income inequality would be at first increased and then decreased with economic development (Kuznets, 1995). Greenwood and Jovanovic (1990) consider that the relationship also shows an inverted " $U$ ” form between financial development and income inequality. Based on the above research, it can be concluded that financial development cannot affect

ZHENG Quanyuan, assistant professor, School of Economics, Henan University, Kaifeng, China.

LIU Zhilin, Ph.D., associate professor, School of Economics, Henan University, Kaifeng, China.

Correspondence concerning this article should be addressed to ZHENG Quanyuan, 1 Jinming str., Kaifeng, Henan, China. 
income inequality directly. However, one of the major functions of financial development is to reallocate the current resources, and this would cause resource allocation to be more equal or more unequal among persons with different income levels. Galor and Zeira (1993) argue that financial development can promote the poor person to increase the human capital investment, and then the income equality would be alleviated with financial development. With a different view, Maurer and Haber (2003) consider that the poor person cannot get the financial service easily, and financial development would provide more investment opportunities for the rich, and then the income inequality would be deteriorated with financial development. However, there are several channels which can provide more financial service for the poor, such as the micro finance (Barr, 2005) and the development of financial intermediaries. Thus, financial development would have an immediate effect on income inequality, but the effect would be either positive or negative.

Many studies use the econometric model to test the specific impact of financial development on income inequality. By using a data set of 49 countries, Li, Squire, and Zou (1998) find that financial development can promote the economic growth, and decrease the income inequality. Clarke, Xu, and Zou (2003) further find that the negative relationship between financial development and income inequality would also be proved when a country is in a low level of financial development, which is against the theoretical argument of Greenwood and Jovanovic (1990). Maurer and Haber (2007) find that financial development can affect income inequality in the emerging economies. However, Kappel (2010) concludes that financial development would have a negative impact on income inequality in high-income countries, while no significant impact on low-income countries. Bahmani-Oskooee and Zhang (2015) conduct a data set of 17 countries, and they find that financial development would have a short-run negative effect on income inequality only in three out of the 10 countries.

As argued by Demirgüç-Kunt and Levine (2009), the current theoretical studies cannot provide a certain conclusion for the impact of financial development on income inequality. In the meantime, the empirical researches also argue that the relationship would be positive, negative, or insignificant. In this study, we conduct a time series of Henan province, and use the method of vector error-corrected to test how financial development affects income inequality, and then evaluate the policy goal of promoting financial sectors in Henan, China.

\section{Material and Methods}

\section{Financial Development and Income Inequality in Henan, China}

We exploit a time series over the period 1978-2014 in Henan, and all data are collected from Henan Statistical Yearbook. In this paper, economic development is measured by gross domestic products per capita and at the constant price of 1978. Income inequality between the urban and the rural is measured by the ratio of per capita disposable income of the urban to that of the rural. Since this paper wants to test the impact of financial development on the income inequality between the urban and the rural, financial development is measured by the total deposits plus the income of the total residents, which is in accordance with Greenwood and Jovanovic (1990).

Figure 1 reports the financial development and income inequality in Henan, China. Henan has been developing economically rapidly, with an annual growth rate of 9.8 percent of the gross domestic products per capita. However, the income inequality between the urban and the rural has not been improved over the period 1978-2014, and the income per capita of the rural resident is only the equivalent of 38.6 percent of that of the urban residents. As for the financial development, it has been increased from 0.104 in 1978 to 1.299 in 2014, by 
the annual growth rate of 7.26 percent. Regarding the correlation among the three variables, financial development is found to be positively associated with per capita GDP, but negatively with income inequality. These would suggest that the policies to promote the financial development would achieve the dual goal to accelerate economic development and reduce the income inequality between the urban and the rural, but need to be tested with the specific method.

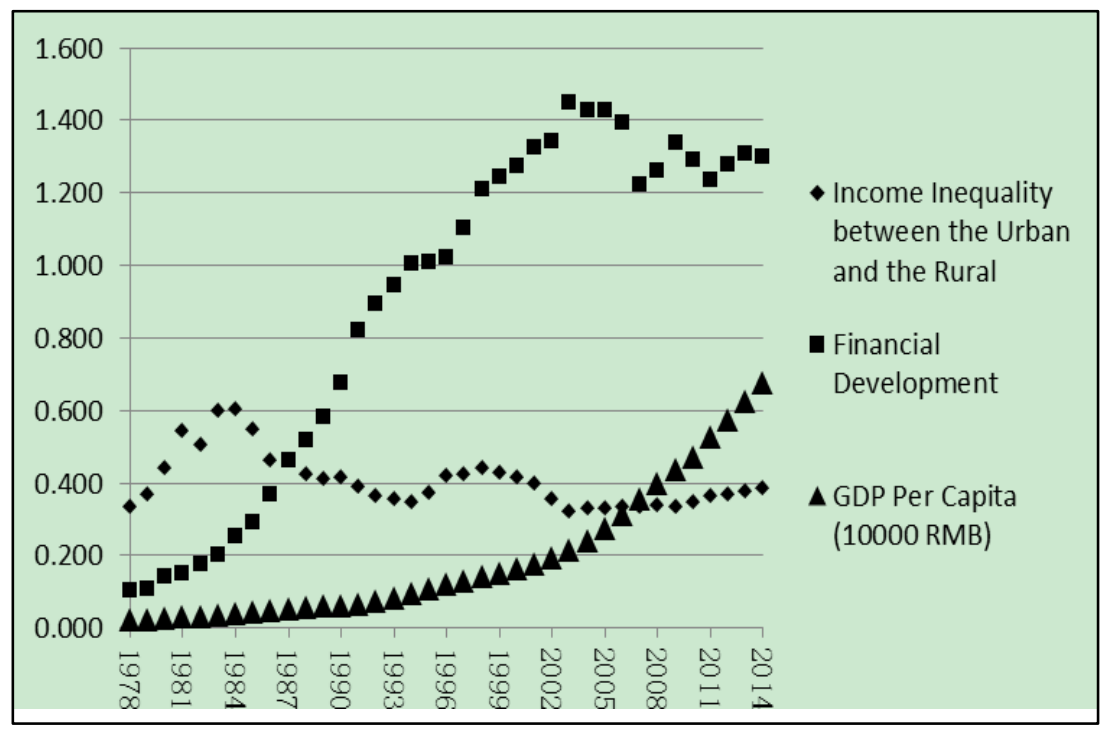

Figure 1. Financial development and income inequality in Henan, China.

\section{Methods}

In order to avoid the spurious regression, it is necessary to conduct the unit root test before the VAR analysis. In this paper, the unit root tests of Dickey-Fuller test (Dickey \& Fuller, 1979), Phillips and Perron (1988) and KPSS test (Kwiatkowski, Phillips, Schmidt, \& Shin, 1992) are used to test the stationarity of the time series. And then, the granger causality test is used to analyze whether there is the directional relationship among the three variables.

In this paper, we use the method of vector auto-regression (VAR) to test the impact of finance development on the income inequality. As one non-structural method, VAR treats every variable as the endogenous variable, and then can exploit the dynamic relationship among variables by the impulse response function (Sims, 1980). In this paper, the VAR model covers three variables, which are the finance development, the income inequality, and the per capita GDP, and the impulse responses can provide the dynamic relationship among the three variables.

\section{Results and Discussion}

\section{Econometrical Test}

Table 1 reports the unit root tests of all variables. Most of the testing results suggest that there is a unit root in the time series of income inequality, financial development, and economic development. Regarding the first-difference terms of all variables, the results show that the three time series are stationary. Thus, it is not feasible to conduct the vector autoregressive analyses with the variables, and the first-difference terms of them are more feasible. 
Table 1

Unit Root Tests of Variables

\begin{tabular}{|c|c|c|c|c|c|c|}
\hline & \multicolumn{2}{|c|}{ Income inequality } & \multicolumn{2}{|c|}{ Financial development } & \multicolumn{2}{|c|}{ Economic development } \\
\hline & Level & First-difference & Level & First-difference & Level & First-difference \\
\hline $\begin{array}{l}\text { Dickey-Fuller } \\
\text { (with intercept) }\end{array}$ & $-1.859 *$ & $-3.610 * * *$ & -0.956 & $-2.891 * * *$ & 0.333 & $-3.185 * * *$ \\
\hline $\begin{array}{l}\text { Dickey-Fuller } \\
\text { (with intercept and trend) }\end{array}$ & -2.420 & $-4.080 * * *$ & -1.709 & $-4.981 * * *$ & -1.906 & $-3.582 * *$ \\
\hline $\begin{array}{l}\text { Phillips-Perron } \\
\text { (with intercept) }\end{array}$ & -2.082 & $-4.127 * * *$ & $-4.612 * * *$ & $-2.795^{*}$ & 0.648 & $-5.407 * * *$ \\
\hline $\begin{array}{l}\text { Phillips-Perron } \\
\text { (with intercept and trend) }\end{array}$ & -3.150 & $-4.040 * *$ & -0.730 & $-5.966 * * *$ & -1.992 & $-5.362 * * *$ \\
\hline $\begin{array}{l}\text { KPSS } \\
\text { (with intercept) }\end{array}$ & 0.442 & 0.127 & $0.617 * *$ & 0.284 & $0.730 * * *$ & 0.139 \\
\hline $\begin{array}{l}\text { KPSS } \\
\text { (with intercept and trend) }\end{array}$ & 0.064 & 0.108 & $0.192 * *$ & 0.099 & $0.161^{* *}$ & 0.053 \\
\hline
\end{tabular}

Notes. “*”, “**”, and “***” denote a significance of 10\%, 5\%, and 1\%, respectively. The hypothesis of Dickey-Fuller test and Phillips-Perron test are that the time series have a unit root, while the hypothesis of KPSS test is that the time series are stationary.

On the basis the results of the unit root tests, the granger causality tests are used to detect the relationship among the financial development, the economic development, and the income inequality, and the tests are conducted by their first-difference terms. Table 2 reports the results, which suggest that financial development can granger cause income inequality and economic development, while only income inequality can granger cause financial development. These results indicate that financial development may have significant effects on income inequality and economic development, and then the policy to promote financial development needs to be evaluated by its effects on income inequality and economic development.

Table 2

Results of Granger Causality Tests

\begin{tabular}{lllll}
\hline \multirow{2}{*}{ Null hypothesis } & \multicolumn{2}{c}{ Lags to include 2 } & \multicolumn{2}{c}{ Lags to include 3 } \\
\cline { 2 - 5 } & F-statistic & Prob. & F-statistic & Prob. \\
\hline Financial development does not granger cause income inequality & 3.788 & 0.035 & 3.202 & 0.040 \\
Income inequality does not granger cause financial development & 0.146 & 0.865 & 2.430 & 0.088 \\
Economic development does not granger cause income inequality & 0.187 & 0.831 & 0.486 & 0.690 \\
Income inequality does not granger cause economic development & 3.623 & 0.039 & 2.257 & 0.106 \\
Economic development does not granger cause financial development & 0.072 & 0.931 & 0.301 & 0.825 \\
Financial development does not granger cause economic development & 1.453 & 0.250 & 3.229 & 0.039 \\
\hline
\end{tabular}

\section{Vector Autoregressive Analysis}

The results presented in Table 1 suggest that the three variables are not stationary, and then it is feasible to use their first-difference terms to conduct the vector autoregressive analysis. By using the Akaike Information Criterion (AIC) and Schwarz Criterion (SC), the results in Table 3 show that AIC and SC are the smallest when the lag of the vector autoregressive model is set to be one. Meanwhile, the results presented in Figure 2 also show that all inverse roots of AR characteristic polynomial are less than one when the lag of the vector autoregressive model is set to be one, which confirms that the vector autoregressive model is stationary and efficient. Thus, it is confirmed that the lag of vector autoregressive model needs to be set to be one. 
Table 3

Testing Results for the Optimal Lag of Vector Autoregressive Model

\begin{tabular}{lllll}
\hline & Lag $=1$ & Lag $=2$ & Lag $=3$ & Lag $=4$ \\
\hline Akaike information criterion & -9.483 & -9.400 & -8.791 & -8.544 \\
Schwarz criterion & -8.697 & -8.040 & -7.849 & -8.011 \\
Adjusted R-squared & 0.316 & 0.388 & 0.513 & 0.555 \\
\hline
\end{tabular}

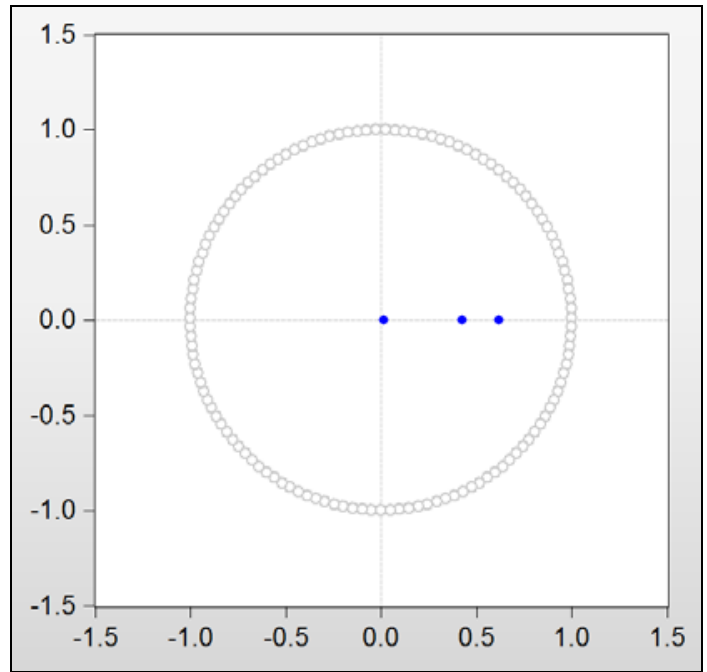

Figure 2. Inverse roots of AR characteristic polynomial (lag =1).

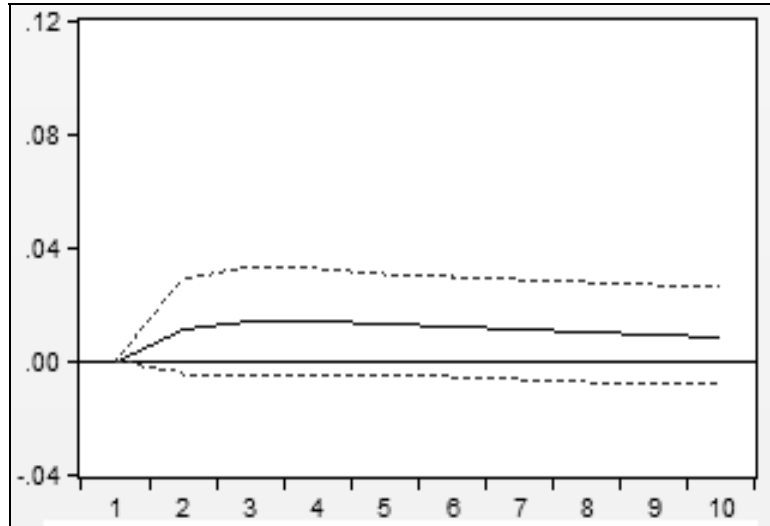

Response of Financial Developmert to Economic Development

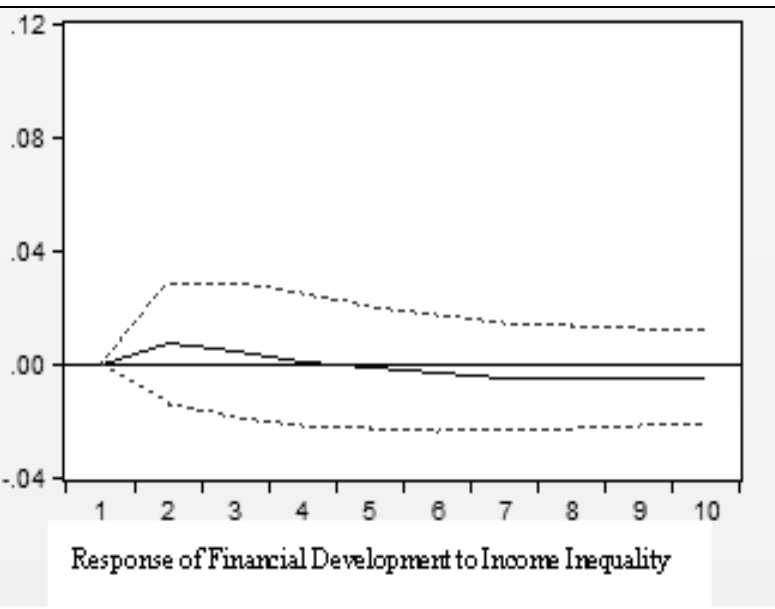

Figure 3. Reponses of financial development on income inequality and economic development.

With the impulse responses function, Figure 3 reports the dynamic impacts of financial development on income inequality and economic development. When there is a positive impulse on financial development, the income inequality would be increased over the period 1-4, and then decreased after the fourth period. So, the results suggest that financial development would not cause more income inequality in the long-run. Regarding economic development, one positive impulse financial development would cause economic development to be increased after the first period, and the response would not be immediate. Thus, it is concluded that the policy to promote financial development can achieve the goal to stimulate economic development and avoid increasing the income inequality. 


\section{Conclusions and Policy Implications}

Finance has been treated as one important tool to promote economic development, and most of China's local governments provide more and more policies to boost financial development. However, financial development also has an effect on income inequality, and the effect would be positive, negative, or neutral. Thus, the policy to promote financial development needs to be evaluated with its effect on income inequality.

In this paper, we conduct a study on a data set of Henan province of China, which wants to provide more preferential policies to promote financial development. Then, this paper uses the vector autoregressive model to detect the dynamic relationship among the financial development, the income inequality, and the economic development, and the results suggest one positive impulse of financial development would cause more rapid economic development and more income inequality immediately. However, the effect of financial development on income inequality would be changed to be negative after the fourth period. Thus, it can be concluded that policies to promote financial development would achieve the dual goals to stimulate economic development and decrease income inequality in the long run.

\section{References}

Bahmani-Oskooee, M., \& Zhang, R. (2015). On the impact of financial development on income distribution: Time-series evidence. Applied Economics, 47(12), 1248-1271.

Barr, M. S. (2005). Microfinance and financial development. Michigan Journal of International Law, 26, 271-296.

Clarke, G. R., Zou, H. F., \& Xu, L. C. (2003). Finance and income inequality: Test of alternative theories (Vol. 2984). Washington, D.C: World Bank Publication.

Dickey, D. A., \& Fuller, W. A. (1979). Distribution of the estimators for autoregressive time series with a unit root. Journal of the American Statistical Association, 74(366a), 427-431.

Demirgüç-Kunt, A., \& Levine, R. (2009). Finance and inequality: Theory and evidence. Annual Review of Financial Economics, 1(1), 287-318.

Galor, O., \& Zeira, J. (1993). Income distribution and macroeconomics. The Review of Economic Studies, 60(1), 35-52.

Greenwood, J., \& Jovanovic, B. (1990). Financial development, growth, and the distribution of income. Journal of Political Economy, 98(5), 1076-1107.

Kwiatkowski, D., Phillips, P. C., Schmidt, P., \& Shin, Y. (1992). Testing the null hypothesis of stationarity against the alternative of a unit root: How sure are we that economic time series have a unit root? Journal of Econometrics, 54(1-3), 159-178.

Kappel, V. (2010). The Effects of financial development on income inequality and poverty. CER-ETH Working Paper, 10/127. ETH, Zürich.

Kuznets, S. (1955). Economic growth and income inequality. American Economic Review, 45(1), 1-28.

Levine, R., \& Zervos, S. (1998). Stock markets, banks, and economic growth. American Economic Review, 88(3), 537-558.

Li, H., Squire, L., \& Zou, H. F. (1998). Explaining international and intertemporal variations in income inequality. The Economic Journal, 108(446), 26-43.

Maurer, N., \& Haber, S. (2007). Related lending and economic performance: Evidence from mexico. The Journal of Economic History, 67(03), 551-581.

McKinnon, R. I. (1973). Money and capital in economic development. Washington DC: Brookings Institution Press.

Ng, S., \& Perron, P. (2001). Lag length selection snd the construction of unit root tests with good size and power. Econometrica, 69(6), 1519-1554.

Phillips, P. C., \& Perron, P. (1988). Testing for a unit root in time series regression. Biometrika, 75(2), 335-346.

Sims, C. A. (1980). Macroeconomics and reality. Econometrica, 48(1), 1-48. 